\title{
Din ve Bilim
}

Muş Alparslan Üniversitesi

İslami İlimler Fakültesi Dergisi

Din ve Bilim - Muş Alparslan Üniversitesi İslami İlimler Fakültesi Dergisi

Region and Science - Journal of Muş Alparslan University Faculty of Islamic Sciences e-ISSN: 2667-7717 Haziran/June 2021, 4(1): 128-140

\section{Nicolai Hartmann ve Scheler'de Değerler Hiyerarşisi, Değer Zıtlıkları ve Çatışkıları}

Hierarchy Contrast and Antinomy of Values According to Nicolai Hartmann and Scheler

\section{Ziya YAVUZ}

Dr., Doctor, Konya/Turkey

ziyayavuz42@hotmail.com

ORCID: 0000-0002-2066-6657

\section{Hasan Hüseyin BİRCAN}

Prof. Dr., Necmettin Erbakan Üniversitesi, Sosyal ve Beşeri Bilimler Fakültesi, Felsefe Bölümü.

Professor, Necmettin Erbakan University, Faculty of Social Sciences and Humanities, Department of Philosophy, Konya/Turkey hhbircan@hotmail.com

ORCID: 0000-0002-6350-4367

\section{Makale Bilgisi | Article Information}

Makale Türü / Article Type: Araştırma Makalesi / Research Article

Geliş Tarihi / Date Received: 20 Mayıs / May 2021

Kabul Tarihi / Date Accepted: 25 Haziran / June 2021

Yayın Tarihi / Date Published: 30 Haziran / June 2021

Yayın Sezonu / Pub Date Season: Haziran / June

DOI: $10.47145 /$ dinbil.939925

Bu makale, Ziya YAVUZ tarafından hazırlanan "Alman İdealizminde Değerler Sorunu ve Nicolai Hartmann'ın Değerler Etiği” (Yıldırım Beyazıt Üniversitesi, Sosyal Bilimler Enstitüsü

(Necmettin Erbakan Üniversitesi SBE Ortak Program), 2021) başl1klı doktora tezinden üretilmiștir./ This Article is extracted from Ziya YAVUZ's doctorate dissertation entitled

"Problem of Values in German Idealism Hartman's Ethics of Values", supervised by Professor Hasan Hüseyin BİRCAN (Yıldırım Beyazıt University, Ankara/Turkey, 2021).

Atıf / Citation: Yavuz, Ziya, Bircan, Hasan Hüseyin. "Nicolai Hartmann ve Scheler' de Değerler Hiyerarşisi, Değer Zıtlıkları ve Çatışkıları / Hierarchy Contrast and Antinomy of Values According to Nicolai Hartmann and Scheler". Din ve Bilim - Muş Alparslan Üniversitesi İslami İlimler Fakültesi

Dergisi 4 / 1 (Haziran 2021): 128-140. doi: 10.47145/dinbil.939925

İntihal: Bu makale, iThenticate yazılımınca taranmıştır. İntihal tespit edilmemiştir.

Plagiarism: This article has been scanned by iThenticate. No plagiarism detected. web: https://dergipark.org.tr/tr/pub/dinbil I mailto: dinbil@alparslan.edu.tr

Copyright $@$ Published by Muş Alparslan Üniversitesi, İslami İlimler Fakültesi / Muş Alparslan University, Faculty of Islamic Sciences, Muş, 49250 Turkey.

Bütün hakları saklıdır. / All right reserved. 


\title{
Öz
}

Hartmann'dan daha önce Max Scheler tarafından değerlerin hiyerarşik yapılarının bütün değer alanlarını kapsayacak şekilde ele alınması, sistematik olmayışı nedeniyle ve belirli türden bir temellendirme eksikliği iddiasıyla bazı yeni Kantçı filozoflar tarafından eleştirilmiştir. İçerikli Değerler Etiği (materiale Wertethik) alanında Scheler'in açtığı yolda ilerleyen Hartmann değerleri tanım, ilişki, olgu vb. açılardan yeniden yorumlarken aynı zamanda değerleri hiyerarşik bir düzen içinde kendi yeni varlık (neue Ontologie) felsefesini temele alan bir yaklaşımla göstermeye çalışmıştır. Bilindiği gibi Hartmann varlığı real ve ideal olmak üzere ikiye ayırmaktadır. Bu ayrıma göre real varlık, varlık kategorilerinin temel ilişkisinden hareketle dört tabakaya ayrılırken ideal varlık, başka türden bir varlığı imleyen özler (değerler) olarak, genellik özelliği gösteren ve gerçekleştirilmelerinden bağımsız olan varlık olarak tanımlanır. İşte ideal bir varlık alanı oluşturduğu düşünülen ve bu alanda duygu yoluyla a priori olarak kavranan ideal özlerin kendi aralarındaki ilişkilerin, tabakalar arası bağıntı, özellik, ortak ve farklı kategorik sınıflandırılması yoluyla yapısal niteliklerinin düzenlenişi bir hiyerarşiye işaret etmektedir. İster real isterse ideal olsun fenomenleri analitik bir yöntemle inceleyen Hartmann tıpkı real alanın fenomenlerinde olduğu gibi ideal alanın fenomenlerinde de kategorik bir yapının varlığının değer ilişkisi bilgisi yoluyla ortaya konulabileceğini savunmaktadır.

Anahtar Sözcükler: Felsefe, Değer, Etik, Hiyerarşi, Hartmann, Scheler,

\begin{abstract}
Hierarchical structure of values has been criticized by some of the new Kantian philosophers for not being systematic and lack of a certain kind of justification of values, which were handled by Max Scheler by all means before Hartmann. Hartmann, pursuing the path pioneered by Scheler in the field of Ethics of Contextual Values (Materiale Wertethik), reinterprets the values in terms of definition, relation, phenomenon, and at the same time, he set forth the values in a hierarchical order with an approach based on his own new entity (neue Ontologie) philosophy. Reality is divided into two as real and ideal by Hartmann. According to this distinction, reality is divided into four groups on the basis of the basic relationship of advertising categories, while the ideal is defined as the essences (values) that signify another type of existence, showing the characteristic of generality and their realization. The arrangement of the structural qualities of the relations between the ideal essences, which are thought to constitute an ideal sphere of existence and which are perceived as a priori through sensation in this field, through the inter-stratified relation, feature, common and different categorical classification points to a hierarchy. Hartmann, having examined the phenomena with an analytical method indifferent to real or ideal, argues that the existence of a categorical structure in the phenomena of the ideal field can be revealed through the knowledge of value relation, just like the phenomena of the real field.
\end{abstract}

Keywords: Philosophy, Value, Ethics, Hierarchy, Hartmann, Scheler 


\section{Giriş: Değerler Hiyerarşisi Sorunu}

Değer etiğinin en önemli konularından birisi, değerlerin hiyerarşik bir sistem içinde gösterimlerinin mümkün olup olmadığının araştırılmasıdır. Bununla ilgili olarak şu sorular sorulabilir: Gerçekten de değerlerin bir sistemi var mıdır? Veya değerler bir sistem içinde gösterilebilir mi? Ya da böyle bir gösterim -eğer mümkünse- gerekli midir? Biz burada bu sorulara değer etiği açısından öncelikle Hartmann ve Scheler özelinde cevap arayacağız.

Antikçağ'da değerlerin bu türden bir düzenlenişi Platon tarafından yapılmıştır. Platon en yüksek değer olarak "mutlak iyi"yi temsil eden tanrı düşüncesini varlık katmanlarının üstüne koyarak aşağıya doğru tinsel, ruhsal ve maddi varlık alanlarını değerlerle bütünleşik olarak sıralamış ve bu yaklaşımıyla varlığı (ideal anlamda) değerle bir tutmuştur. Onun bu yaklaşımı değerlerin hiyerarşik düzen içinde gösterimi açısından Ortaçağ'da olduğu gibi çağımızda da bu konuda araştırma yapanlar için önemli olmuştur denilebilir (Özlem, 2010: 175). Nitekim 19. yüzyılda Platon'un bu görüşlerine benzer şekilde bir derecelendirme ilkin Scheler tarafından değerlerin birbirinden farklı kategorik özelliklerine dikkat çekilerek yapılmıştır. Scheler'e göre değerler kendinde varlık niteliği taşıyan mutlak özler oldukları için onların varoluşları her şeyden bağımsızdır. Her ne kadar insan kendisi dışındaki başka bir şey, kişi ya da nesne ile ilişkisinde onlar hakkında bir değerlendirme yapıyor olsa da değerler, insanların ve ilişki kurulan nesnelerin nitelikleri olamazlar (Bircan, 2015: 23). Scheler'in değerleri ideal varlıklar olarak tanımlaması, onlarla değer duygusu yoluyla temas kuran insan açısından değerlerin bir düzen içinde gösterimini mümkün kıldığ söylenebilir. Ancak onun bu incelemesi bir sistem bütünlüğü göstermediği gerekçesiyle tartışma konusu olmuştur.

Diğer taraftan, değerleri farklı bir gerçeklik (ideal) üzerinden ontolojik katman yasalarıyla kategorize eden ve onları genel bir hiyerarşi içinde gösteren Hartmann, değerler alanında fenomenolojik açıdan bir incelemenin mümkün olabilmesi için bu alanın da hiyerarşik olarak düzenlenmesinin gerekliliğine dikkat çekmiştir. O'na göre değerler, değer duygusu yoluyla elde edildiklerinden onları nerede ve nasıl kavrayacaksak o şekilde aramalıyı. Ancak değerlerin değer duygusundan hareketle sınıflandırılması oldukça zor bir iştir. Çünkü değerler, birbirlerinden farklı hiyerarşik ve kategorik özellikler gösterirler. O nedenle bu yapıda tek yönlü ve birlikli bir yaklaşım, sistem kurma açısından yeterli olmamaktadır (Hartmann, 1949: 171). Hartmann'a göre değerler alanında birliğin kurulabilmesi, ancak değer ilişkisi bilgisi yoluyla mümkün olabilir. O nedenle insanın içinde bulunduğu ve birçok değerin birbirine karıştığı bütün etik durumlarda değerin değerle ilişkisi dikkate alınmalıdır. Zira insanın davranışını belirleyen değer duygusu, belirli bir hiyerarşiye görelidir (Hartmann, 1949: 271).

Hartmann, bu konuyla ilgili olarak Sokrates'in insanın varlık özüne ilişkin görüşüne atıfla, onun düşük bir değer olan kötü değerini iradi olarak seçmeyeceğini vurgular. Ancak çözülmesi gereken bir sorun olarak doğal davranıştaki yanılgıyı neyle açıklayacağımızı sorar ve bu konudaki çıkmazı şöyle açıklar:

(...) Eğer iradenin yapısında değerli olana yönelmek varsa zayıflık ve duygulanım iradeyi değerli olandan nasıl ayırabilir? Bu yanılgı insanın yapısında olmayan şeytanca bir yanıltmadır denilebilir ancak cevap bundan farklıdır. Duyguya bağlı irade sadece aşağı değere yönelir. O dış yönüyle moral olarak ayrımlanmamış maddi değerlere bağlı olup onda yüksek değerler yoluyla yani ahlaki değerler yoluyla bir seçme kabiliyeti eksiktir. Böylece problemin çözümünün değerler hiyerarşisinde olduğu görülmektedir. Bu yüzden bütün ahlaki değer bilincinin, hiyerarşi bilincine ihtiyacı vardır (Hartmann, 1949: 272).

Hartmann, Kant'ın ahlak yasasına ve Platon'un en yüksek iyi görüşüne, onların değerler arasında belirli türden bir hiyerarşi gözetmeksizin aşağı değerleri bir tek yüksek değere göreli olarak yorumlamalarından dolayı karşı çıkmaktadır (Hartmann, 1949: 274). Zira değerler arasında hiyerarşik bir yapının kurulabilmesi ancak değerlerin ortak nitelikleri kriter olarak alındığında mümkün olabilir 
(Kraft, 1951: 22). O nedenle bir tek yüksek değere göreli davranmak, iradi bir çabayı ve belirli türden bir amacı gerekli kılabilir; ancak, insan bütün davranışlarında iradesiyle hareket edemez.

\section{Değer Alanının Çok Boyutluluğu ve Derecelendirme İlişkisi}

Hartmann'a göre değerlerin çok boyutluluğu, içerik açısından değişken oluşları ve değişik değer yüksekliklerinde farklı anlam kazanmaları nedeniyle onların hiyerarşik bir düzende gösterimi oldukça zor bir iştir. Değerler, aslında değer duygusunda verili olduğu şekliyle ve asıllarında oldukları gibi kademeli olarak iç içe geçmeliydi; ancak, değerlerin niceliksel ve niteliksel açıdan farklı oluşları buna imkân vermemektedir. O nedenle bir derecelendirme konusu olan içeriği farklı değerlerin farklı değer yükseklikleri gerektirmesi görüşü burada geçersiz olmaktadır. Zira birbirinden farklı değer içeriklerine sahip değerler, aynı değer yüksekliği derecesinde bulunabilirler. Örneğin maddi değerler alanında tamamen farklı iki maddi-şey aynı şekilde değerli olabilir. Bu durum ahlaki değerler için de geçerlidir. Değerler arasında bir derecelendirme ilişkisinde değerleri herhangi bir değer yüksekliği görüşüne göre nitelemek, tutarlı gözükmemektedir. Hartmann'a göre, değerler ideal alanın gerçeklikleri oldukları için bir değerin yüksek oluşunun onun geçerliliğinin bir nedeni olduğu ve mutlaklığa yakın olduğu görüşü bir yanılgıdır. Bu nedenledir ki bir değerin gerekli oluşu, onun geçerli ve yüksek oluşuna işaret etmez. Ayrıca maddi şey değerleriyle ahlaki değerlerin ilişkisi bir derecelendirme konusu değildir (Hartmann, 1949: 276).

Değerler alanında bir derecelendirme biçimi olarak değer yüksekliği ilişkisinden başka, bir de değer gücü ilişkisi vardır. Bu ilişkide değerler çok çeşitli türden olabilirler ancak, değer gücünün çeşitli derecelerde bulunması değer yüksekliğini göstermez. Hartmann'ın değerler alanında, bilinen kategorik varlık yasasından farklı olarak ileri sürdüğü katman teorisine göre yüksek değerler güçüz, aşağı değerler güçlüdürler. Ve ayrıca yüksek değerler, genelde karmaşık (komplex) yapılar olup aşağı değerler basit (elementar) yapıdadırlar. Değerler dünyasında aşağı kategoriler güçlü ve bağımsızken, güçsüz ve bağımlı olanlar ise yüksek ve karmaşı yapılardır. Buradan da anlaşılacağı üzere ideal dünyanın (değerler dünyasının) yükseklik ve güçlülük ilişkileri, reel dünyanın yasalarının tam tersidir (Hartmann, 1949: 277).

Buradan hareketle denilebilir ki değerlerin çok boyutlu yapıları, değerleri güçlü-güçsüz, yüksek-aşağı gibi derecelendirme süreçlerinde önemli derecede engel teşkil etmektedir. Ancak böyle olmakla birlikte bu alanda büyük oranda Scheler'in tespitlerinden hareket eden Hartmann'ın ortaya koyduğu değerlerin hiyerarşik düzenleri düşüncesi, hem yaklaşım tarzı açısından ve hem de yapılan tutarlı tespitler açısından araştırmaya değer niteliktedir.

\subsection{Scheler'e Göre Değerler Hiyerarşisi}

Değerleri içerikleri açısından inceleyen ve içerikli değer etiğinin (materiale Wertethik) kurucusu sayılan Scheler, değerleri bir sistem içinde gösterebilmek için onları dirimsel (vital), duyusal (emotionale), tinsel (geistige) ve mutlak (absolute) olmak üzere dört ana grupta toplamaktadır. Bunlardan ilki olan dirimsel değerler, insanın yaşamını sürdürmesini mümkün kılan hava, su vb. yaşamsal değerlerdir. İkincisi duyusal değer grubu olup bu değerler hoş-hoş olmayan, yararlı-zararlı gibi değerlerdir. Üçüncü gruptaki değerler kültür değerleri olarak üçe ayrılırlar: a) estetik değerler, b) ahlaki değerler, c) bilgi değerleri. Dördüncüsü, en yüksek değer grubunu oluşturan mutlak değerlerdir. Bunlar da kutsal değerlerden oluşur (Scheler, 1921/2007: 103-109).

Scheler'in yapmış olduğu başka önemli bir ayrım da kişi değerleri (Personwerte) ile şey değerleri (Sachwerte) arasındaki ayrımdır. Kültür değerleri ile birlikte bütün nesnel değerler bu gruba girer. Kişi değerleri ise kişinin kendisinin (eigen) değerleri olup bu değerler doğal olarak şey değerlerine üstündürler. Çünkü bu değerler insanın tutum ve davranışlarında ortaya çıkan ahlaki değerlerdir (Bochenski, 2019: 170). 
Değerler alanında var olan sıra düzeni içindeki bir değer yüksek, bir başka değer ise aşağ olarak belirebilir. Bu olgu değerlerin özünde bulunan bir şeydir. İnsan değer duygusunda sadece değeri değil aynı zamanda değerin derecesini de duyar. Buna göre üstün tutulan değer, tercih etmede kendini gösterir. Bir değeri diğerine tercih etme, dışsal bir nedene bağlı olabildiği gibi a priori de olabilir. O nedenle değerler arasındaki sıralama, tercih ediminde açıkça ortaya konulur (Akarsu, 1994: 167).

Hartmann, değerler hiyerarşisinin neye göre oluştuğu sorununun değerler felsefesinde ayrı bir problem alanı olduğunun altını çizer ve Scheler'in konuyla ilgili tespitlerine dikkat çekerek değerlerin hiyerarşik düzeninde değer yüksekliğinin temel bir fonksiyonuna değinir. Hartmann'a göre Scheler, değer yüksekliği sorununu sadece ahlaki değerler alanında değil bütün değerler alanında araştırmıştır. Scheler'in değerlerin yükseklik dereceleri ile ilgili tespitleri şu şekildedir: Birincisi, değerler sürekli olduğu ölçüde, daha başka bir ifadeyle zamansız oldukları ölçüde daha yüksektirler. Burada söz konusu olan değer taşıyıcının sürekliliği değil, bizzat değerin zamansız oluş karakteri esastır. Bununla ilgili birkaç örnek verilecek olursa: Örneğin hoş değeri, belirli bir duygunun sürekliğine bağlıdır. Bunun gibi maddi şey değerleri de belirli bir içsel ve dişsal durumun sürekliliğine bağlıdır. Buna karşılık tinsel değerler, deneyi aşan bir geçerliliğe sahip oldukları için geçici hükümlerin ve durumların üzerinde bulunurlar. Bu nedenle tinsel değerlerde zamanla ilgili bir niteleme söz konusu değildir. Ayrıca moral değerler kendilerini bağlayan edim değerleriyle tamamlanmış sayılmazlar. Örneğin sevgi değeri yalnızca sonsuzluk perspektifinden bakıldığında anlamlı kılınabilir (Scheler, 1921/2007: 88). İkincisi, paylaşılabilen ve paylaşıldığı halde bölünmesi gerekmeyen değerler yüksek olurlar. O nedenle materyal maddi şeyler, herkesçe paylaşılmaya müsait olduklarından bu türden değerler paylaşıldığı ölçüde azalır. Ancak tinsel şeyler (geistige Güter), paylaşılamaz olup kendilerinden pay alınmasından bağımsızdırlar. Örneğin birleştirici niteliliği olan moral değerlerin oluş tarzları herkes için olup onlardan pay almak kimseye göreli değildir. Dolayısıyla bu değerler, yüksek değerlerdir. Üçüncüsü, bu sınıftaki değerler, temellendirme ilişkisine göre ele alınmaktadır. Buna göre materyal olarak temellenen değer serbest, bağımsız, aynı zamanda ilksel ve aşağ 1 değer olup yüksek değer onda temellenir. Bu temellendirme ilişkisi prensip olarak böyledir. Dördüncüsü, bu gruptaki değerlerde değer yüksekliği ile tatmin olmanın derinliği arasında değer duyumuna bilincinin refakat ettiği bir varlık ilişkisi bulunur. Bu ilişkide değer bilinci belirleyici rol oynar. Beşinci ve son olarak değer yüksekliğinin bir işareti, belirli bir değer duygusunun görelilik derecesinde bulunur. Örneğin haz değerleri sadece hazzı duyan varlık için anlam doludur ve yaşam değerleri sadece canlılığı duyan varlıklar içindir. Fakat moral değerler, sadece aynı şekilde moral varlıklar için değil bilakis kişinin kendindeki değer kalitelerinin herhangi birine göreli olmayan değer duyumlarıdırlar (Scheler, 1921/2007: 93-94-95). Hartmann'a göre yukarıda siralanan her bir kriter, moral değerlerin yaşam değerlerine üstünlügünü göstermeye yeterlidir. Bunun için herhangi bir işarete gerek yoktur. Büyük değer sınıfları arasındaki küçük farklılıklar da zaten bu tarzda görünür kılınamaz. Ancak etik için değer sınıfları ve grupları çerçevesinde değer yüksekliklerinin bu farklılıkları önemlidir. Zamanüstülük, bölünemezlik, temellendirilebilirlik ve aksiyolojik mutlaklık gibi bu dört özelliğe sahip olan değerler, ahlaki değerlerdir ve başka bir işarete gerek duymazlar. Ancak ayrıştırma, tatmin duygusunun derinliğine göre değişik derecelerde olabilir. Örneğin haklılık, doğruluk, huzur, cesaret gibi değerlerde duygu derinliğine göre değişimler tespit edilebilir (Hartmann, 1949: 280).

Değerlerdeki bu değişimler doğru olarak D.v. Hildebrand'ın Ahlaki Eylem Düşüncesi adlı eserinin değer denkliği bölümünde işlenmiştir. Hildebrand'ın görüşüne göre, her değer için sadece kendisinin yapısına uygun tarzda bir tavrın varlığı söz konusudur. O nedenle hiç kimse bir ve aynı şeyi hem çok hoş ve hem de itici bulamaz. Ona göre değer ve tavır alma içeriğinin arasındaki ilişki, varlık yasasınca belirlenmiş bir ilişkidir ve değiştirilemez nitelikte olan bu yasalılık, hem pozitif ve hem de negatif olanda mevcuttur (Hartmann, 1949: 281). 
Diğer taraftan değerlere yüklenen niteliklerin (değerlendirme) ilk örneğinin antik Grek felsefesinde Aristoteles'in Nikomakhos'a Etik adlı eserinde incelendiği görülmektedir. Aristoteles'in geliştirdiği erdem sıralaması, aynı değerde bir çeşitlilik olmayıp ahlaki yüksekliğe göre derecelendirilmiş, kendisine göre ayarlanan sıralamayla kısmen uyuşan erdemleri gösterir. Bu değer yüklemlerinin arka planında, niceliksel ve niteliksel olarak derecelendirilen değeri onaylayan ve reddeden edimler sıralanır: Övgü-yergi, sevgi-nefret gibi. Ancak bu erdemlerin değer yükseklikleri, yalnızca insanın davranışında tespit edilebilirler (Hartmann, 1949: 282).

Hartmann, değerlerin yapısından ayrılmayan bir hiyerarşik yapının objektif olarak var olduğunu ve bu yapının değerlerle aynı varoluş tarzına ve aynı ideal kendinde oluşa sahip olduğunu ileri sürmektedir. O'na göre insanın bu hiyerarşik yapıyı değiştirmesi zordur. Çünkü insandaki değer bilinci sınırlıdır. Hartmann, tercih etmenin anlamı üzerindeki temel belirlenimler ve insana ait değer bilincinin ayrımı ile değerlerin kendinde oluşa sahip hiyerarşisi arasındaki ilişkinin temellendirilmesinde Scheler'in görüşlerinin önemine vurgu yapar ve şu tespitlerde bulunur: “Tercih etme, değerler üzerinde yargının bir edimi olmayıp bilakis o, dolaysız değer duyumunda ilksel bir seçimdir. Değer yükleminin ve değer yanıtının bütün ayrımlaması bu seçime ve aynı şekilde değer duygusuna karışmış olana ilişkindir". Yukarıda da kısmen değinildiği gibi değer yüksekliği onun tercih edilmesine bağlı değildir. Ancak derin bir değer duygusunda dışarıdan bir etkiye açık olmayan aksiyolojik yükseklik duygusu (anlamı) diyebileceğimiz bir anlam vardır. Bizim değer anlamımız, değer alanının birlikli yapısına değil, özel bir içeriğe ve onun özel bir ilişkisine bağlıdır. Gerçi tercih olgusunda bilgimiz bulunur, ancak bu belirleyici bir kriter değildir (Hartmann, 1949: 287). Nitekim Alman yeni kantçllardan Rickert'e göre de düşüncemize anlam ve yön veren, sadece geçerli bir değer görüsüdür (Aster, 1980: 371).

\subsection{Hiyerarşik Düzende En Yüksek Değer Sorunu: Bir Tek İyi}

Bilindiği üzere etikle ilgili felsefi görüşlerin çoğunluğunda en önemli sorunlardan biri de değer yargısının rölatifliği ve buna bağlı olarak da değerlerin rölatifliği sorunudur. Ancak Hartmann'a göre değer yargısının rölatifliği, değerlerin rölatifliği anlamına gelmez. Çünkü gerçek bir değer görüsüne sahip bütün pozitif moraller (ahlaki yaşantılar), değer varlıklarını a priori kavrarlar ve bu kavrayış değerlerin tarihi açıdan rölatifliğini değil, değer görüsünün rölatifliğini gösterir. Buna göre her geçerli moral, a priori bir kavrayışla birkaç veya tek bir değer tanır ve bütün başka değerleri onun üzerinden ele alır. Böyle bir yaklaşım onda bir eksiklik yaratmaz. Ayrıca herhangi bir moral, ne kadar tek yönlü olursa olsun, bir gerçeklik içeriğine sahiptir (Hartmann, 1949: 287).

Diğer taraftan hiyerarşik düzende birliğe ait olması gerekenin (seinsollen), tek anlamlı olması ve bu amaç için doğrudan ya da dolaylı olarak tek'e yönelmiş bir birlik hedefinin önceden konulmuş olması gereklidir. Çünkü olması gereken, ancak birlikli bakış açısının bir şey sunmadığı durumlarda tek ve anlaşılabilir belirli bir değeri, kavranan değerlerin çeşitliliği üzerine koyabilir. Ancak, olması gereken, herhangi bir kurala göreli değildir. Bu nedenle denilebilir ki bütün geçerli morallerin geçiciliği, değer bakışının sınırlılığının sonucu değil, daha çok birlik prensibinin herhangi bir kurala dayanmayan niteliğinden dolayıdır (Hartmann, 1949: 288).

Nitekim tek başına bir birlik prensibi olarak ileri sürülen en yüksek iyi değeri, içerik bakımından belirsiz olup bir değer duygusu olarak duyulamazdır. Dolayısıyla postulat olarak ortaya konulamayan böyle bir prensip, değer bakışı da kazanamamaktadır. Ayrıca şu da belirtilmelidir ki en yüksek iyinin, merkezî ahlaki değer olmasıla ilgili bir birlik olsa bile bu merkezî konum görünmez olmakta ve değişik ahlaklarda farklı yorumlanmaktadır. Çünkü Hartmann'a göre iyi, değere yönelen bir edim (akt) olduğu için o ancak içerik olarak duyumsanabilir (Kuçuradi, 2013: 90). Fakat o, en yüksek iyi nitelemesiyle bir birlik prensibi olarak ileri sürülemez. O nedenle bu konuyla ilgili en yetkin formülasyonu Plotinos yapmıştır: İyi, düşünülebilir olanın diğer tarafıdır. Yani iyi, irrasyoneldir (Hartmann, 1949: 289). 
Hartmann'a göre değerlerin bir sistem içinde gösterimi, noktasal bir en yüksek birlik idesi olmasa da mümkündür. Değerlerin ideal dünyasında, varlık kategorilerinde olduğu gibi sonucu görünür olan tek ve hâkim bir prensip olmayıp bilakis kendi kendine işleyen ve diğerini gerektiren prensipler geçerlidir. O nedenle bütün zamanların moralleri, iyiyi birlik değeri olarak görmüş olsalar bile tek yüksek bir değerin içeriksel olarak anlaşılırlığ1 ortaya konamaz ve bu görülemeyen, duyulamayan değer içeriği boş, tek yönlü bir kavram olarak kalır. Ancak her şeye rağmen iyinin kapalı değer kavramı bir şekilde, alanın tamamında bütünlük ilişkisi olarak bulunabilir ve belki de o, onların yapılarının, düzenlerinin ve içsel yasalılıklarının bir prensibi olabilir (Hartmann, 1949: 299).

Kısaca etik prensibin birlik talebi olan bir tek iyi, Hartmann'a göre geçerli bir postulat değildir. Çünkü bütün değerlerin kendisine göreli olacağı böyle bir en yüksek prensip, düşünülebilir olsa bile tanımlanabilir ve herkesçe duyulabilir olamayacağı için geçerli kabul edilemez. Ancak böyle bir prensip, yine de değerler sisteminin bütünlüğünün sağlanmasında yardımcı olabilir.

\subsection{Değerler Çoğulluğu ve Etik Monizm}

Değerler, değer duygusu yoluyla kavranabildikleri için değer dünyasında genel ispatlar, indirgemeler ve tahminler bulunmaz; burada sadece aşamalı olarak değer bilincinin olguları takip edilir. Bu alanda birliği sağlayacak olan en yüksek değere ulaşmada a priori bir yaklaşım gereklidir. Buna göre birlik prensibi, basit ve temel olabilen değerlerde bulunduğu gibi karmaşı değerlerde de bulunabilir. Basit (elementar) değerlerde en temel ve en genel nitelikler bulunabilirken, karmaşık (komplex) değerlerde yalnızca aksiyolojik olarak en yükseğe ulaşılabilir. Hartmann'a göre birlik prensibini sağlayacak olan en yüksek değere ulaşmada izlenen her iki yol da soyut bir inşa değildir. Hartmann burada hareketin prensibinin hareketin kendisi olmadığı, yaşam prensibinin yaşamın kendisi olmadığı düşüncesinden hareketle değer dünyasında değerden farklı olan genel, hâkim bir prensibin olabileceğini savunmaktadır (Hartmann, 1949: 292).

Öte yandan Hartmann'a göre en yüksek değere yer bulma işinden vazgeçilebilir. Çünkü değer görüsü, ilk baştan itibaren değer ilişkisi üzerine kurulmak zorundadır. Bu ilişkisel yaklaşım; kapsam, temellendirme ilişkisi, yakınlık ve ayrılık, yapı ilişkisi, içerik, yükseklik düzeni ve geçerlilik alanlarının kesişimi üzerine inşa edilmelidir. Onlar, birlikli olabildikleri gibi zıtlık ve karşıtlık ilişkisi içinde de olabilirler. Değer antinomilerinde değer duygusu çözümsüz kalabilir. O nedenle aranan birlik prensibi bir harmoni postulatı olmamalıdır. Çünkü bu durumda fenomende saklı olan problem gözden kaçırılabilir. Hartmann bu noktada Hegel'in düşüncesine dikkat çeker ve Hegel'in, “bütün felsefi sistemlerde hakikatten bir parça bulunur ve felsefenin görevi bu parçaları mutlak hakikat olarak felsefenin ideal sisteminde birleştirmektir" düşüncesini, etik için faydalı bir görüş olduğu gerekçesiyle savunur. Hartmann'a göre -izm'leri aşma burada da bizim için bir görevdir (Hartmann, 1949: 293).

Hartmann'a göre eğer, değerler kendi oluş yasaları (ideal alanda değerlerin kategorik yasaları) dikkate alınarak çözümlenmeye çalışlırsa monizmin (özellikle Alman idealistlerinin) spekülatif yorumlarından kurtulunabilir ve böylece bütünlüklü bir değerler sistemi kurmak mümkün olabilir. Bunun için izlenmesi gereken yol, değerleri kendi çeşitlilikleri (farklılıkları) içinde ele almak olmalıdır. Nitekim değerlerin hiyerarşik bir sistem içinde gösteriminin birlik prensibince sağlanamayacağını düşünen Hartmann, kendi ontolojik görüşüne de uygun olarak, değerlere varlıksal bir nitelik atfetmekte ve değerleri bu çerçevede bir düzene sokmak istemektedir. O'na göre böyle yapılması durumunda, monizmin spekülatif konstrüksiyonlarından kurtulmak ve böylece değerler dünyasının yapısını çözümlemek mümkün olabilecektir. Bunun için öncelikle değer zıtlıkları ve antinomilerin incelenmesi gerekmektedir. 


\section{Değer Zıtlıkları (Wertgegensaetze) ve Değer Çatışkıları (Antinomien)}

Hartmann'a göre değerlerin hiyerarşik bir düzen içinde gösteriminin mümkün olabilmesi için birbirine zıt ve birbiriyle çatışan değerlerin kategorik açıdan incelenmesi gerekmektedir. Çünkü söz konusu değerler, değer duygusunda zor kavranan ve sadece içeriksel açıdan betimlenebilen değerlerdir. Buna ilaveten değerler arasında oluşan çatışkı, değerli-değersiz olarak değil, değerdendeğere olduğu için çözüm daha da karmaşık bir hal almaktadır. Filozofa göre, değerin değere karşı olduğu bir durumda hata yapmadan bir çıkış yolu bulmak imkânsızdır. Çünkü böyle bir durumda karar verme insanın elinde değildir. $\mathrm{O}$, öyle veya böyle bir seçimde bulunacaktır ve eylemsizliği seçmesi durumunda bu karar da pozitif bir karar olacaktır. Burada içine girilen pozisyon, her ne pahasına olursa olsun birçok şeyden herhangi birisini seçmek zorunda kalınmasıdır. Burada insan, gerçekte devamlı bir değer anlaşmazlığını çözme ve ortaya çıkabilecek herhangi bir suçluluk durumuna cevap verecek şekilde karar verme zorunluluğu ile karşı karşıya kalmaktadır (Hartmann, 1949, 295). Ayrıca değerlerin birbirlerine zıt ve çatışık yapıları, karşımıza değerlerin gerçeklik kazanması sırasında çelişik durumlar çıkarabilmektedir. Örneğin bir an haklılık durumunun göz ardı edildiğini düşünürsek, adalet ve sevgi değerleri ilişkisinde sevginin ön plana çıkarak adaleti dışta bıraktığını görürüz. Bu örnekte görüldüğü üzere problem, durum ve değer karşıtlı̆̆ bağlamında ortaya çıkmaktadır. Bu nedenle bir değer olarak durum (situation) da, uyuşmazlığın temel bir faktörü olmaktadır (Hartmann, 1949: 297).

Diğer taraftan Hartmann, bu sorunun çözümü bağlamında, kategorik varlık zıtlıkları sistemine benzer bir yapının, düşünülebilir değerler alanında da mevcut olduğunu ve bu alandaki değerlerin genel bir yasaya bağlanabileceğini savunmaktadır. O'na göre somut tek bir değere yöneltilen değer görüsü, sınırlı olduğundan değer alanlarının tamamını dolduramaz. O nedenle söz konusu alandaki değerlerin bir sistem içinde gösterimi, ancak genel bir yasaya göre mümkün olabilir (Hartmann, 1949: 298).

\subsection{Modal Değer Zitlıkları}

Yukarıda, değerlerde bir zorunluluk niteliğinin bulunduğu dile getirilmişti. Hartmann'a göre bu zorunluluk, ontolojik anlamda bir zorunluluktan farklı ve mümkün olandan da (nesnel gerçeklikten de) bağımsızdır. Söz konusu bağımsızlık, kendine bağlı zorunluluk dışında hiçbir şeye bağlı olmayan mutlak bir bağımsızlıktır ve bu mutlak bağımsız oluş-zorunluluk, değer karakterine ait olduğu ölçüde değerin kendisidir. Söz konusu bağımsızlık, değerlerin ideal oluşuna ve başka türlü var olanlar üzerine yücelik kattığı gibi değerlerin kendine özgü genelliklerini de geçerli kılar. Sonuçta bu mutlak güce boyun eğen değer duygusu, içsel olarak ona yükselir ve böylece kendi ethos'unda (değerle bezenmiş huy) ondan pay alır ve bu onun en yüksek derecesi olur. İnsandaki değer duygusunun böyle bir süreç sonucunda bu tarz derecelendirilmesi değerlerin insan davranışlarındaki gücünün bir işaretidir. Hartmann'a göre değer duygusunda mutlak zorunluluk adına en derin ifadeyi, ödev görüşünü kutsallaştırarak gerekli oluşu ön plana çıkaran Kant ortaya koymuştur. Bu yaklaşım tek yanlı da olsa moral yasaya saygı anlamında akıllı varlığın hiçbir şeyle karşılaştırılamayan tercihte bulunma durumunu ifade etmektedir (Hartmann, 1949: 299).

Diğer taraftan antinomik ilişki açısından bakıldığında, değerin yapısında hem bir zorunluluk ve hem de onu duyan insan açısından bir özgürlük özelliğinin bulunduğu görülür. Yani zorunluluğu duyan kişi, o zorunlulukla zorlanamayacağını da bilir. İnsanın bu özgürlüğü, zorunluluğun kendi özgürlüğü değildir, ancak ona bağımlıdır. Bu zorunluluk mümkün olanla (realite) bağıntılı değildir. Eğer öyle olsaydı kişi, doğa yasaları tarafından belirlenmiş olurdu. O nedenle gereklilikteki (sollen) zorlama gücünün eksikliği ahlaki varlık için inşa edilmiş temel bir değer olarak burada ortaya çıkmaktadır. Değerlerin bu ikili yapısı dünyada, onları etkin hale getiren kişisel öznenin tavrına görelidir. Bu suretle edimler, kendileri yoluyla olması gerekenin gerçekleştirilmesi için çabalayan özne 
aracılığıyla bir derecelendirme ifadesi olan en yüksek ahlaki değerlerin taşıyıcısı olurlar. Bunu mümkün kılan ise her iki değerin (zorunluluk-özgürlük) antinomik ilişkisidir (Hartmann, 1949: 300).

Ayrıca başka türden bir antinomi, realitenin içine geçen gerekliliğin yapısında ortaya çıkar. Yani olanla olması gereken arasında her zaman çatışkılı bir durum vardır. Ancak gerekliliğe ait içeriğin bir parçasının reel olması çok bir şey ifade etmez. Çünkü etik gerçeklikte değerler, olmak (sein) ve olmamak'ın (nichtsein) ortasında sadece bir yönleriyle gerçektirler. Burada ikili bir değer ilişkisine göreli olarak bir değerin gerçekleştirilmesi değerli olduğu gibi bir değerin yok edilmesi de değersizlik anlamı taşır (Hartmann, 1949: 301). Kısaca söylenecek olursa amaçlanan değerin gerçekliği karşısında gerçekleştirilecek olan değerin olması, kendinde bir değer yüksekliği ölçüsü taşımaz. $O$ nedenle antinomi bu noktada da ortadan kalkmaz ve gerçekleştirme olgusunda tekrar güçlü olarak ortaya çıkar. Örneğin, mükemmellik değerine karşı olması gerekenin tamamlanmamışlığı veya başarı değerine karşı ulaşılamaz olanın varlığı gibi. İşte bu yüzdendir ki burada ortaya çıkan değer parçalanmışlı̆̆ bütün moral yönelimli edimlerde görülür. Çünkü aktivite, çaba, istem ve bunlara eşit olanlar, bir yönelim formu olan gerçekleşme gibi çift değer bağlamında bir arada konumlanırlar (Hartmann, 1949: 303).

\subsection{Bağıntısal (Korelatif) Değer Zıtlıkları}

Hartmann'ın değer zıtlıklarının antinomik karakteriyle ilgili görüşüne göre, değerlerin birbirleriyle bağıntıları söz konusu olduğunda amaçlanan değerin, amaç değerinden başka bir değer taşıyıcıya sahip olduğu düşüncesi öne çıkmaktadır. Buna göre amaçlanan değer nesneyi, diğeri amacın öznesini bağlar. Burada nesne ve özne bir ve aynı değer amacıdır ve her ikisi de aynı şekilde değer taşıyıcıdır. Bundan dolayıdır ki özne ve nesnenin değer zıtlığı, böyle bir amacın içinde kökleşir. Bunun dışında özne, bütün etik değerlerin taşıyıcısı olarak temel bir değere sahiptir. Bu temel değer, başkalarının da pay sahibi olduğu şey değerleri ile ilişkili olup örneğin, iyi bir şey yaptığımda onu birisi için yaparım ya da kötü bir şey yaptığımda o başkası için kötülük olur. O nedenle kişisel özne, ilk baştan amaçlanan nesnenin değer içeriğinde işlevseldir ve bu fonksiyonuyla o, amacın kendi nesnesi olmaktadır. Ayrıca kişisel özne, nesne olarak ahlaki davranışın bir şartıdır ve kökensel değer olarak mümkün olan edimlerin en genel temel değeridir. Kişisel öznenin bu yapısı, somut yaşamda, etik ideal yapıda ve etik gerçekliğin geçerli bütün moral yapılarında varlık ve fonksiyon olarak bulunur (Hartmann, 1949: 305-306).

Hartmann'a göre değerler arasında eğilim ve karşı olma, aktivite ve atalet gibi birbirine bağlı zıtlıklar vardır. Bu zıtlıklar ahlaki değerler arasında etkinlik kazanırlar. Çünkü belirli bir anlamda her değer bir ilk hareket ettirici olmakla birlikte, bu hareketi reel alana kişisel öznenin aktivitesi olmadan kendisi aktaramaz. Ancak bu aktivite bir varlık formu olarak düşünülmemelidir. Zira her insanda, eylemde bulunsun veya bulunmasın, asıl olan, ahlaki değer duygusudur. İnsandaki bu ahlaki oluş, eğilimlere sınır koyarak duraksız, devamlı bir harekete, içsel bir karşı duruş sergiler. Onun kendini bu şekilde sınırlaması ona, kendi ahlaki varlığına sahip olma imkânı tanır. Burada hemen belirtelim ki eylemsizlik gücü, olması gerekene (seinsollen) karşı ahlaki varlığın karşı-ağırlığı, eğilimin sürekliliğinde onun geri duruşudur. Bu, eylemsizlik, pasiflik ve etik tembellik olmayıp etik özün ontolojik tembelliği, aktivite durumunda gerçekleşen değer içeriğinin direnci, etik varlığın tutucu karşı eğilimidir. Bu anlamda o, bir değer, aktivite değerinden başka bir şey olmayan bir güç değeridir (Hartmann, 1949: 307-308).

Burada ayrıca insandaki yaratıcı ahlaki özü ortaya çıkarmak için bir değerin tek yönlü yükseltilmesi ya da zıt değerlerin aynı anda gerçekleşmelerinin tanınması gerekmektedir. Bu iki yoldan herhangi birinin tercih edilmesi bütün bir aktivitenin yöneldiği ahlaki “öz" ü ve insanda yaratıcı olanı meydana çıkarır. Genişliğine doğru gelişmede de bu yaratıcılık rol oynar. Çünkü ulaşılmak istenen yaratıcı birlik, erişilebilir bütün değer içeriklerinin, heterojen olanlar da dâhil olmak 
üzere bir değer tipinin birliğinde ortaya çıkar. O nedenle böyle bir değer tipinin aksiyolojik genişliği bu yüzdendir ve değerli olan her şey bu birlikte görünür kılınmıştır (Hartmann, 1949: 309).

Hartmann'a göre uyum (harmoni) ve uyumsuzluk, değerler alanında başka bir zıtlık boyutunu ifade ederler. Her bir yapıda olması beklenen ve mükemmele ulaşabilen statik bir değer olarak uyum, bir kendi değerdir. Bir insan, bir gelişme, herhangi bir varlık, başkasıyla kendiliğinden bir uyum içinde olabilir. Ancak bütün etik gerçeklikte ve yapılarda, bu statik oluş dinamik oluşun karşısındadır. Herakleitos'un "evrende savaş" dediği şey, etik gerçeklikte de vardır. Bu savaş kendini, bir oluş durumu olarak sonsuz yaşam akışının bütün bir çeşitliliğini yansıtan tavırlar olarak, yeniden yeniye duraksamayan ilişkilerin ortaya çıkışı olarak, aynı şekilde duraksamayan uyuşmazlıklar ve bilmeceler olarak gösterir. Bu, etik varlığın içeriksel sonsuzluğunu, zenginliğini, sonsuz yeniliğini ve doyumunu gösteren şeydir (Hartmann, 1949: 310). İnsanın amaca yönelik eyleminin olumsuz bir sonucu gibi duran uyumsuzluk değeri, aslında değer görüsüne ve değer duygusuna yeni bir içerik kazandırmaktadır. O nedenle ahlaki yaşam gerçekte, verili uyuşmazlıkların yaşanmasıdır denilebilir. Bu uyuşmazlıkların kişi yoluyla yaratıcı çözümü, yine onun varlığına bağlıdır ve bu anlamda her yaşam durumu böylece değerlidir. Dolayısıyla denilebilir ki insan hayatı, durumların bir akışı olup içerikli temel değer bir defa yaşanan duruma içkin bir olgudur.

Yukarıdaki açıklamalardan hareketle denilebilir ki değerlerin ideal dünyasında hiyerarşik bir düzenin varlığını savunan Hartmann, böyle bir düzenin değerlerin varlık yapılarının incelenmesiyle mümkün olabileceğini düşünmektedir. O'na göre değerler derecelendirme, zıtlık, öncelik-sonralık, güçlülük-zayıflık gibi ve ayrıca kendi aralarındaki bağlantısal ilişkiler yoluyla bir düzene sokulabilir ve bir sistem içinde gösterilebilir. Ancak burada, değerlerin duyuma-duyguya dayalı gerçekliği dikkate alındığında, ortaya konulmak istenen sistemin herkes için geçerliliği konusu açıkta kalmaktadır. Fakat yine de sistem düşüncesine dayalı bir çabanın sürdürülmesi, etik olguların yorumlanmasında yol gösterici olacaktır.

\subsection{Niteliksel Değer Zıtlıkları}

Hartmann, değerler arasında niteliksel açıdan birbirinden farklı değerlere dikkat çekerek onları genel ve özel olarak ikiye ayırmaktadır. O'na göre genel değerler toplumun değerleridir. Özne bu değerleri, kendi değer görüsü sınırlı olduğu ve bu genellik bütün değerleri kapsamadığı için tam olarak kavrayamaz. Nitekim yalnızca maddi şey ve şey ilişkisi değerleri kişiye özeldir. Bu tür değerler, çoğunlukla şeyleri ve ilişkileri kapsayan tinsel değerler olduklarından genelleştirilemezler. Örneğin vatan sevgisi, yaşanmışlığa dayanan herhangi kutsal ve benzeri bir şey, bunlardan sayılabilir. Bu durum, kişi değerlerinde daha belirgin olup bu değerler ancak bireyselleştirilebilir değerlerdir. Bunların dışında ontolojik açıdan bir ve tek olan bireysel değer içerikleri, yani kendileri bireysel olan değerler de vardır. Bunlardan kendine ait olma değeri (eigenwert), değerler alanında içeriğe sahip bir değer olarak genellik ve bireyselliğin kategorik zıtlığını da içinde barındırır (Hartmann, 1949: 314).

Söz konusu değer zıtlığı, niteliksel bir zıtlıktır. Örneğin bir kendi değeri olarak herkes için geçerli olan eşitlik değeri, aynı zamanda genel bir değer olduğu için ancak niteliksel açıdan incelenebilir. Nitekim Hartmann, hukuktaki kişilerin yasa önünde eşit olmaları görüşünü buna dayandırmaktadır. O'na göre insanlar ne kadar farklı olurlarsa olsunlar, bütün bireysel tercihlerin sınırının bulunduğu belirli bir yaşam temeli vardır ve onların hem yargı önünde hem de vicdani açıdan eşit olmaları gerekmektedir. Hatırlanacağı üzere Kant da "kategorik imperatif"te, bu değer düşüncesini formel olarak ortaya koymuştu. Eşitlik ilkesi burada içsel bir yöne veya bir amaç düşüncesine (maxim) yönelik olup buna göre maxim şu şekilde belirtilmişti: "İsteyebileceğin iyi aynı zamanda herkesin isteyeceği iyi olmalıdır". Ancak Hartmann, insanların yasa önündeki ideal eşitliğini değerli bulmakla birlikte kişilerin gerçekte sadece doğal değil ahlaki olarak da eşit olmadığını savunmakta ve bu eşitsizlik olgusunu da değerli bulmaktadır (Hartmann, 1949: 315). 
O nedenle, durumda (situation) bulunan değer duygusu ne kadar farklılaşır ve bireyselleşirse değer içeriğinden aldığı pay o kadar içsel ve varlık yapısına bağlı olur. Bu bakımdan denilebilir ki bütün şemalaştırmalar ve genellemeler, değer içeriğini fakirleştirmedir. Ve bütün derinleşme, onurlandırma, değerlendirme, durumda kendine özgü düzenleme, etik zenginlik, moral gelişme, aksiyolojik çoğalma ve doyum anlamına gelir. Zira hiçbir sınırsız insani tasarım, gerçek durumların bireysel içeriğini tahmin edemez. Bu nedenledir ki Hartmann, etiğe nedensel bir yaklaşımı geçersiz sayar (Hartmann, 1949: 317).

Diğer taraftan Hartmann, genel ve bireysel değerlerin bireysellik karakteri gösteren özel tip bir değerde sentezlendiğini ileri sürmektedir. O'na göre böyle bir sentezleme, yeni bir kendi değeri ortaya çıkarmaktadır. $\mathrm{O}$, bu yeni tip değere ırklarla ilgili biyolojik tip değerlerini ve ayrıca tarihte ortaya çıkan moral tiplerini örnek göstermektedir: Atinalılar, Spartalılar, Romalılar, Germanlar, gibi. Ayrıca belirtilmelidir ki bu sentez değerlerde, uçta olan karşıtlıklar eriyip kaybolmaz. Bu tiplere geçiş değerleri de denebilir. Bu tipte genel, bireysel olmaz, bireysel genel olmaz. Bunlar sentezin dişında kalırlar ve bu ilişkide hiçbir yapay ilişkilendirme geçerli değildir (Hartmann, 1949: 319).

Denilebilir ki genellik değeri, en basit hukuki düzenden başlayarak en yüksek kültür idealine kadar bütün etik değerlerin değer tözüdür (Wertsubstanz). Genellik, ahlaki değer taşıyıcısının değerlerini taşıdığı ölçüde evrenselleşir. Bu bağlamda genellik, yüce tarzlı değer taşıyıcıdır. $O$, insanın uzak hedefler peşinde, geniş ufuklu ödevlerinin peşinden gitmesini sağlayan bir tözdür. Kişi bu ödevleri yerine getirirken kendini feda etme derecesine kadar ilerleyebilir. Ancak bu kendini feda etme, genellik değerinde gerçek değerlerin, ödevlerin ve hedeflerin bulunması ve onda gerçekleştirilebilir olması durumunda anlamlıdır. Onun ancak bu suretle topluma değer katması mümkün olabilir ve ancak bu durumda insanın ahlaki yükselmesinden bahsedilebilir.

Genel bir değer ifade eden toplumun, kategorik bir nitelemeye göre kişiliği yoktur. Sadece bireyin sahip olduğu kişilikte, bir özne, bir bilinç ve kendine özgü edimler ve içerikler vardır. Ayrıca özne ve kişi tek anlamlı kategorik bağımlılık ilişkisi içindedirler; çünkü yüksek bir yapı olarak kişi, aşağı bir yapı olan özneyi gerektirir. O nedenle toplumda gerçekleşen değerler toplumun değerleri olmayıp bilakis kişinin değerleridir. Hukuk, devlet düzeni ve sosyal kurumlar, tek bir varlığı değil toplum varlığını konu edindikleri için değer olarak yüksek kabul edilmezler; çünkü bunlar ahlaki değer taşıyıcısı değildirler (Hartmann, 1949: 323). Oysa kişi, genellik değerine kendisini vermek suretiyle kendinde yüksek değeri gerçekleştirir. Vatan ve millet için kendini kurban etmenin anlamı budur. Buradan da açıkça anlaşılacağı gibi değer taşıyıcısı olarak kişinin kendisi, genellik değerinden daha yüksek değere sahiptir. Bu yüzden kişisel etiğin, tek yönlü toplumsal etiğe karşı böyle bir temellendirmeden dolayı üstünlüğü vardır denilebilir (Hartmann, 1949: 325).

Bütün bunlar gösteriyor ki, Hartmann'a göre değerlerin ontolojik açıdan bireysel ve genel olma özellikleriyle ilgili olarak kendi yapılarından kaynaklanan niteliksel zıtlıklar vardır. Ancak bu zıtlıklar, değer içeriği ile ilgili zıtlıklar olup durumda (situation) ortaya çıkarlar. Ona göre durumlara bağlı kalarak genel geçer yasa düşüncesini savunmak, kişinin değer duygusunu yok sayacağından ve onu formel bir eşitlik düşüncesine tabi kılarak ve kişiler arasındaki eşitsizliği ortadan kaldıracağından, kabul edilemezdir. Çünkü genelliğin kişiye ait bir değer ve aynı zamanda bir değer özü olduğu dikkate alındığında, kişinin değer duyumu daha önemli olmakta ve bu yüzden de kişisel etik kendi içinde çeşitlilik barındırması açısından diğer etiklere üstün tutulmaktadır.

\subsection{Niceliksel Değer Zıtlıkları}

Burada her değer zıtlığının değer antinomisi olmadığının altını çizmemiz gerekiyor. O nedenle belirtelim ki genellik ve bireysellik arasındaki değer zıtlı̆̆ı, antinomik düzeyde bir zıtlık olmayıp her iki değerin de kendine göre aksiyolojik üstünlükleri vardır. Genellik büyük vasıflı yapılara dair olup onun değerleri makrokozmiktir. Buna karşılık bireyin değerleri, ahlaki değerlerdir. Genellik değerleri (toplum, tarih vs. değerleri) açısından bakıldığında, bireyin değerleri, bu değerlere uygunluk 
gösterdiği ölçüde geçerlik ve anlam kazanırlar. Genellik yaşantısı, bireyi kendi kurallarına uymaya zorlar ve ona boyun eğdirir. Ancak konuya birey değeri açısından bakıldığında birey, kendine özgü değerleri yaşamalı ki bunlar toplum değeri düzeyine erişebilsin. Zaten bireyin bu özel yaşantısı olmadan toplum düşüncesi anlamsızdır. Bireyselliğin (Individualite) toplumun var oluş ve değerleri üzerinde yargı oluşturması düşüncesi, genellik değeri açısından da aynı şekilde mümkün gözükmektedir.

Hartmann, etik felsefesindeki toplumculuk ve bireycilik ayrımına dikkat çekerek bu görüşlerin kendilerinde gerçeklik parçaları taşısalar da tek başlarına geneli kapsayamayacaklarını savunmaktadır. Ona göre her iki öğreti de bazı konularda insanın somut hayatında olmayan soyutlama ve değer izolasyonu yanlışına düşmektedirler. Toplum-genellik etiğinde (Allheitsethik) genelliğin kendisi sadece bir soyutlamadır. Onun bireylerde görülmesi, toplumun bireylerden oluşmasından dolayıdır (Hartmann, 1949: 327). Birey-toplum ilişkisinde birey kendine özgü amacı kısmen de olsa kendine dönük olarak gerçekleştirebilir ancak genel (toplum), kendini parçanın bir aracı yapmadan amacını gerçekleştiremez. Diğer taraftan bireycilik için de durum bundan farklı değildir. Çünkü birey kendini toplumdan soyutlayamaz. Birey kendisi için bir çevre olan toplum içine doğar ve kendisini bu çevrede gerçekleştirir. Kişi toplum içinde birlikte olmada, eğitimde, kültürde, yaşam ve dünya yorumunda nesnellik kazanır; ancak, toplumsallığın kabul edilmemesi durumunda bireyin amaçlılığ da diyalektik olarak kendine geri döner. Birey ve toplum değerleri sadece ontolojik değil aynı zamanda aksiyolojik olarak da iç içedirler. Ve bunların değer zıtlığındaki bağıntıları, farklılıklarından daha çoktur. Niceliksel değer zıtlığının sınırı işte burasıdır (Hartmann, 1949: 329).

Hartmann'a göre, genel ve bireysel değerler arasındaki bağlantısal ilişki şu şekilde gerçekleşmektedir:

(...) Genelin (toplum) ilgisi sadece kendi parçası olan bireye değil aynı zamanda bireyselleştirmenin yüksekliğinedir de. Tek kişi ne kadar çeşitli ve zengin içerikli bir farklılık arz ederse o oranda toplumun tamamı öyle zengin ve değer dolu olur. Birlikte yaşam, eşitliğin bir fonksiyonu olmayıp onun formu, eşit olmayanların birliği şeklindedir (Hartmann, 1949: 331).

Buradan hareketle denilebilir ki hangi türden olursa olsun değer zıtlıkları, yapay bir çabayla ortadan kaldırılmamalıdır. Zira bu durum, değer dünyasının kendi karakteristik özelliğidir. Ayrıca değer uyuşmazlığındaki gerilimin varlığı, insandaki yaratma gücünü, kendini ortaya koyma edimini ve insani sorumluluk yeteneğini geliştirmektedir.

Ayrıca şu da belirtilmelidir ki değerlerin çok boyutluluğu ve birbirlerine zıtlığı, birlik prensibinden daha az doğal değildir. Zira doğal yoldan gelişmiş veya tarihsel olarak yaratılmış empirik bir etik gerçekliğin somut çevresi içinde dil, ahlak, ruhsal yönelim ve kültür gibi, bireyin içinde doğup büyüdüğü ve pay aldığı bütün değerlerin açılımları bulunur. O nedenle Hartmann'ın da belirttiği gibi tek bir insanlık dili ve tek bir insanlık kültürü olmayıp bilakis halkların kendilerine ait farklı kültürleri vardır (Hartmann, 1949: 334).

Görüldügü üzere gerek niteliksel olsun ve gerekse de niceliksel olsun düşüncede ya da aktüalitede ortaya çıkan değer zıtlıkları, antinomi niteliği taşımamaktadırlar. O nedenle denilebilir ki bu türden zıtlıklar birbirini, gereksinen ve tamamlayan zıtlıklardır. Örneğin toplum kültürünün oluşabilmesi için bireylerin farklı değer duyumları ne kadar önemli ise bireyin duyduğu değeri anlamlandırabilmesi için de toplumun varlığı o derece önemli olmaktadır. Hartmann, burada daha çok kişinin değer duyumunu öne çıkararak aktüalitede ortaya çıkan zıtlıkların bu uyuşmazlık üzerinden çözümleneceğini savunmaktadır. Zira onun düşüncesinde insan özgür iradesiyle hareket edebilen bir doğa varlığı olmakla birlikte aynı zamanda değer yaratabilen bir varlıktır da. 


\section{Sonuç}

Buraya kadar yapılan araştırmada varılan sonuca göre Hartmann, değerleri bir sistem içinde gösterme çabasında büyük ölçüde Scheler'den hareket etmiştir. O, Scheler'in değerleri bir sistem içinde gösterebilmek için onları dirimsel (vital), duyusal (emotionale), tinsel (geistige) ve mutlak (absolute) olmak üzere dört ana grupta toplayan sınıflandırmasından farklı olarak onların varlık yapılarının incelenmesinin gerekliliğine işaret etmektedir. O'na göre değerler derecelendirme (Schictung), temellendirilme (Fundierung), zıtlık (Gegensaetzlichkeit), tamamlayıcılık (Komplementar), kademe yüksekliği (Ranghöhe), güçlülük-zayıflık (Wertstaerke) gibi ve ayrıca kendi aralarındaki bağlantısal (relationel) ilişkiler yoluyla bir düzene sokulabilir ve bir sistem içinde gösterilebilir. Ancak bu tür sınıflandırmalar, değerler arasındaki bir hiyerarşiyi göstermesi ve buradan bir değerler sistemi kurulmasının imkânı açısından önemli olmakla birlikte tinsel değerler alanında da olsa değerleri başka bir dünyanın (ideal) mutlak gerçeklikleri olarak ele almak, değerlerin duyguya dayalı gerçekliği dikkate alındığında gerek temellendirmek, gerek gerçekleştirmek ve gerekse de değerlerin birbirleri ile olan ilişkilerini bir bütün oluşturacak biçimde bir sistem içinde sunmak oldukça zor bir iş olarak karşımızda durmaktadır.

\section{Kaynakça}

Akarsu, B. (1994). Çă̆gaş Felsefe. İstanbul: İnkılap.

Aster, V. E. (1980). Geschichte der Philosophie (17.Auflage). Stuttgart: Kröner Verlag.

Bircan, H. H. (2015). Değerler Bilançosu. Konya: Çizgi.

Bochenski, J.M. (2019). Çağdaş Avrupa Felsefesi. Serdar Rıfat Kırkoğlu (Çev.). Ankara: Fol.

Hartmann, N. (1949). Ethik (Dritte Auflage). Berlin: Walter de Gruyter \& Co.

Kraft,V. (1951). Die Grundlagen einer Wissenschaftlichen Wertlehre (2.Neubearbeitete Auflage) Wien: Springer-Verlag.

Kuçuradi, İ. (2013). İnsan ve Değerleri (5. Baskı). Ankara: Türkiye Felsefe Kurumu.

Özlem, D. (2010). Etik-Ahlak Felsefesi (2. Baskı). İstanbul: Say.

Scheler, M. (1921/2007). Der Formalismus in der Ethik und die Materiale Wertethik (2. Auflage). Elibron Classics, Halle: a.d.S. Verlag von Max Niemeyer. 